prepared as a needle, m.p. $116^{\circ}$, from resorcin, introducing an aldehyde between the two hydroxyl groups by Gatterman's reaction, acetylating these hydroxy groups, and then oxidating the aldehyde to carboxylic group. In this oxydation, the yield of diacetoxy-benzoic acid was found to be best when three times as much of $\mathrm{KMnO}_{4}$-were used as it was theoretically calculated. 3-Acetyl-4,5-dihydroxycoumarin, mp. 158, was obtained in $30 \%$ of the yield, condensing 2,6-diacetoxybenzoic acid chloride with sodium acetoacetic acid ethyl ester in the solution of the dried ether. In this case, almost no 3-acetyl-4-hydroxy-5-acetoxycoumarin was obtained.

The antibacterial activities of these derivatives of coumarin will be published in the following paper.

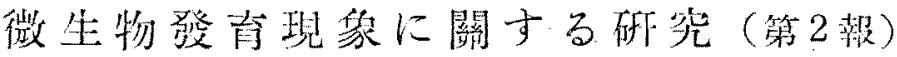 \\ 細崩發会曲線の推計學的取报い方
}

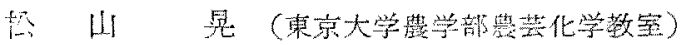 \\ 照初27年5月10日曼㻎 \\ Studies on the Microbial Growth. Part 2. A Statistical Treatment of \\ the Bacterial Growth Curve.
}

By Akira Matsuyama (Dept. of Agr. Chem., Fac. of Agr., University of Tokyo)

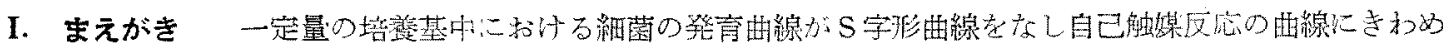
てよく一致していることは MCKENDRICK and PAI(1) (1911), ROBERTOSON(2) (1922, 1923), THORNTON(3) (1922)，LOTKA(4) (1925) 等によって報告されている. 叉 PUTIFY and GREAvES(5) (1932) は微生物の代謝

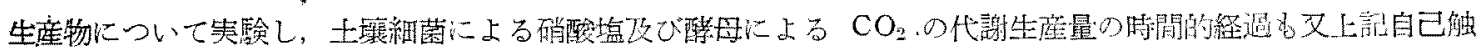

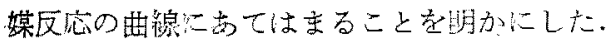

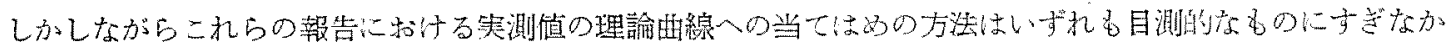

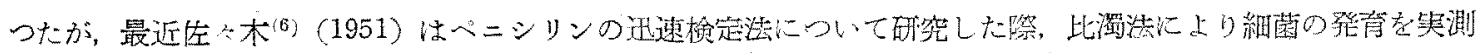

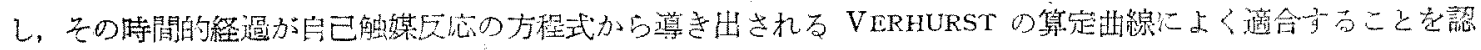

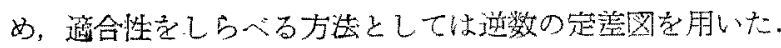

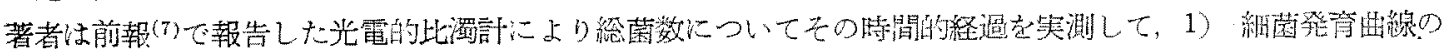

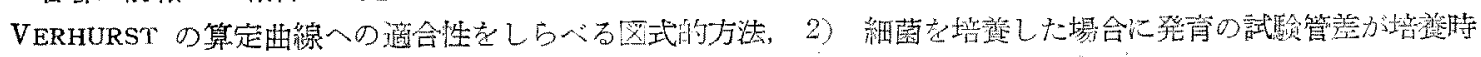

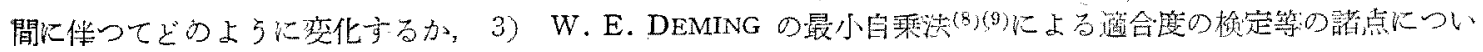
て計算应びに検討を行つたので艺の結果について報告卞る。

\section{II. 細菌発育曲線の測定}

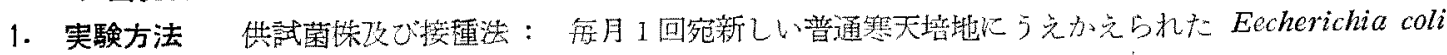

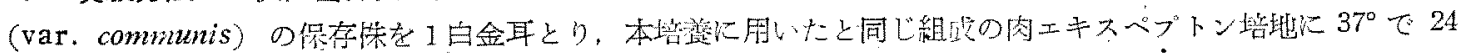

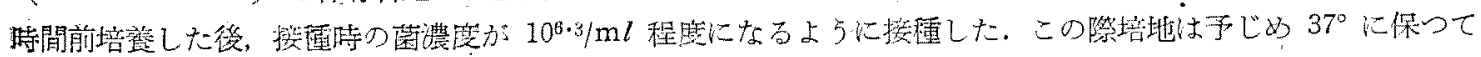

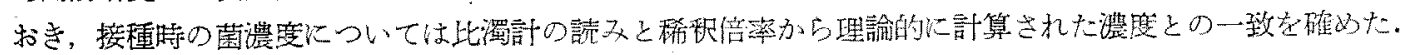

培地の調掣：測定用境地の組成及び $\mathrm{pH}$ は次のるのを用いた。

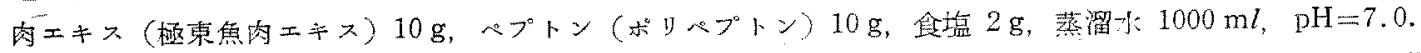

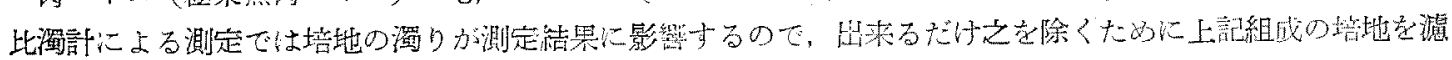

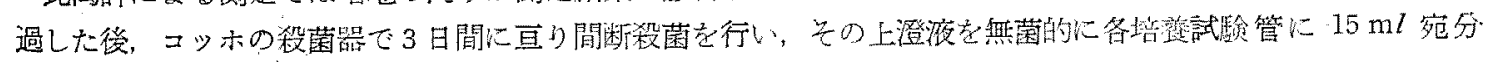

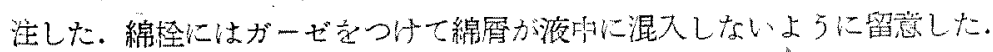

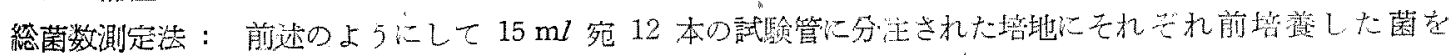

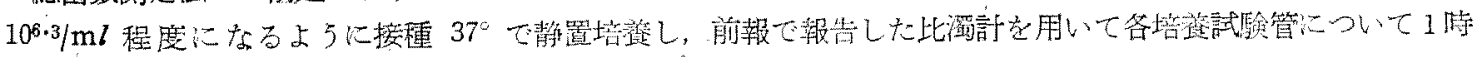

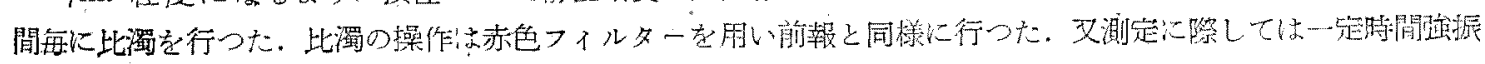

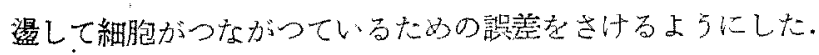

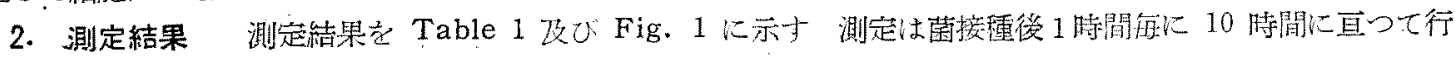




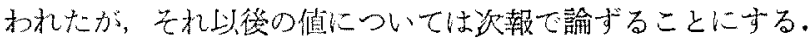

Table 1: Growth of E. coli (by turbidimetry)

\begin{tabular}{|c|c|c|c|c|c|c|c|c|c|c|c|c|}
\hline (hrs.) & 0 & 1 & 2 & 3 & 4 & 5 & 6 & 7 & 8 & 9 & 10 & 24 \\
\hline $\bar{I}$ & 1.017 & 1.292 & 2.242 & 6.042 & 18.57 & 53.22 & 93.06 & 105.0 & 110.5 & 115.8 & 120.3 & 360.1 \\
\hline$u_{\Gamma}^{3}$ & 0.010749 & & 0.0266 & 15 & 2.597 & & 18.748 & & 23.95 & & 23.45 & \\
\hline
\end{tabular}

$\vec{I}$ indicates the mean value of the observed readings $I$ of twelve tubes, using the photoelectric turbidimeter.; $u_{\Pi}^{2}$ is the mean square.

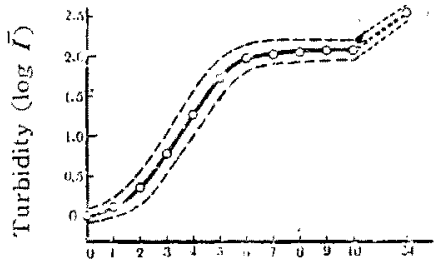

Hours of incub. (t)

Broken lines show the confidence limits $\left(X_{7}\right)$ at $P=0.05$

Fig. 1. Growth Curve of Escherichia coli (var. comomunis) (from data in Table 1)

\section{III. 適合性の図式検定法}

自己触媒反応におけると同様の関係が一定培地中に

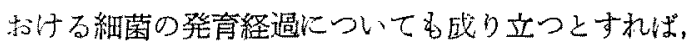
細菌の増㒹速度は次式によつて示される。

$$
\mathrm{d} y / \mathrm{d} t=r y(L-y) \cdots \cdots(1)
$$

但し $y^{\prime}$ は総菌数， $t$ は培翼時間， $L$ は兽殖の最大 值，r瑺数である。これを蝵分すすれば $\ln y /(L-y)$ $=r t+C \cdots \cdots \cdot(2)$ 但し $C$ は積分常数. 今 $t=a$ のとき $y=L / 2$ であるとすれば $C=-r a$

この関係を（2）式に代入して $\ln y /(L-y)=r(t$ $-a) \cdots \cdots(3) \quad \therefore y=L / 1+e^{-r(t-a)} \cdots \cdots(4)$

（4）式は VERHURST（1838）か人口增加曲線として発表した算足曲線に外ならない。

1. 逆数の定差図について 細菌発育曲線の（4) 式への当てはめの図式的方法として佐ヶ木 (1951) は (4) 式について $h$ を常数として $e^{-r h} \cdot L / y(t)-L / y(t+h)=e^{-r h}-1$ 即ち $1 / y(t)$ と $1 / y(t+h)$ との間に線型

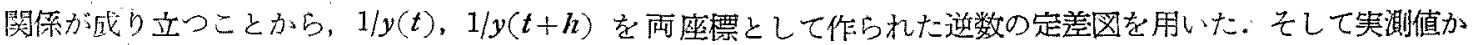
ら作られた定差図上で直線上の点が得られたことから細菌発育曲線がよく（4）式に適合することを報告した。 この際 $y$ の值としては $\log n / n_{0}$ に相当する值が用いられた。即ち接種時（ $t=0 ）$ 润濁菖（此濁計の読み）を

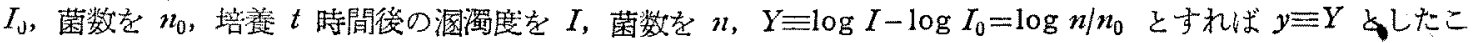
とになる.しかし（4）式で $t=0$ の坥合 $y=L /\left(1+e^{r a}\right)$ となるので，むし発育曲線が（4）式当てはまると 寸れば $y \equiv Y+\varepsilon$ [但し $\left.\varepsilon=L /\left(1+e^{r a}\right)\right]$ とするのが妥当である. 笑用上は $Y \gg \varepsilon$ が成り立つときには $y \equiv Y$ と

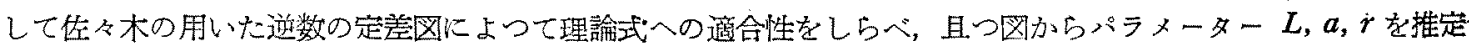
する方法はきわわてすぐれている、しかし接種時及び菌数の比較的增加しない脬導期の值についてはこの方法で

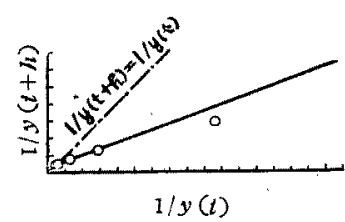

(a) $y \equiv Y$

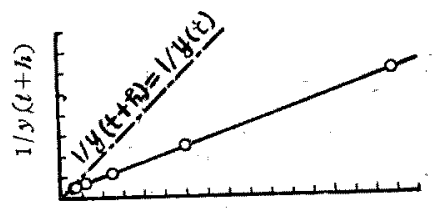

$1 / y(t)$

(b) $y \equiv Y+\varepsilon$

Fig. 2. Diagrams of finite differences $1 / y(t+h)$ to $1 / y(t)$

The point corresponding to $1 / y(0)$ is not showed, because of $y(0)=0$.

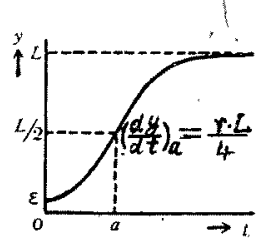

Fig. 3. The Schema of Logistic Curve (5)
は $y \equiv Y$ と考えたために起る直線からのズレをさけ ることは出来ない. Table 1 の英測值から $y \equiv Y$ と してこの方法によつて作られた Fig. 2 (a) の定差図。 、はこのズレを示している. Fig. 2 (b) は $y \equiv Y+\varepsilon$ として作られた定差园である。

2. $\varepsilon$ 項の導入とその際の定差図 $\quad y \equiv Y$ とする 
ことによつて起る図上の点のズレを除くために $y \equiv ゙+\varepsilon$ とすることは堎尊期等 Y

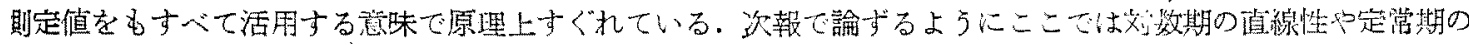

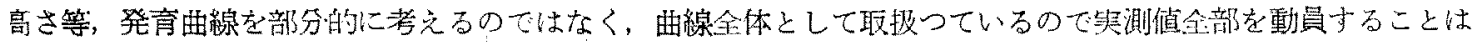

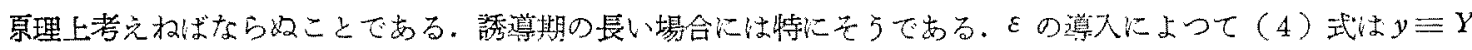

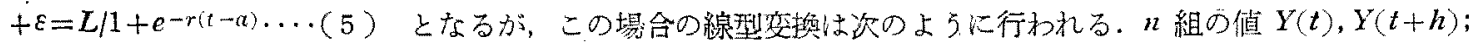
$Y(t+h), Y(t+2 h) ; \cdots ; Y[t+(n-1) h], Y(t+n h)$ 劣考光, $\quad Y(t) \equiv Y_{0}+y_{0}, \quad Y(t+h) \equiv Y_{1}+y_{1} \quad[$ 但L $y_{0} \equiv Y(0) ， y_{1} \equiv Y(1)$ とし $y_{0}, y_{1}$ は固定］とすれば（5）式加ら

$$
\frac{1}{x(t+h)+\varepsilon}=\frac{e^{-r h}}{Y(t)+\varepsilon}+\frac{1-e^{-r h}}{L} \quad \therefore \quad Y_{1}+\left(\frac{A+B y_{0}+\varepsilon}{B}\right) \frac{Y_{1}}{Y_{0}}+\left(\frac{-1+B y_{1}+\varepsilon}{B}\right)=0 \cdots(6)
$$

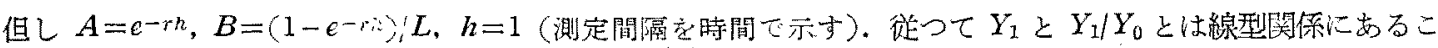

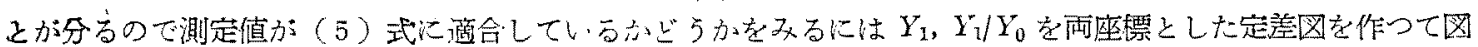
上の点の直線炏をしらくるとよいことになる。

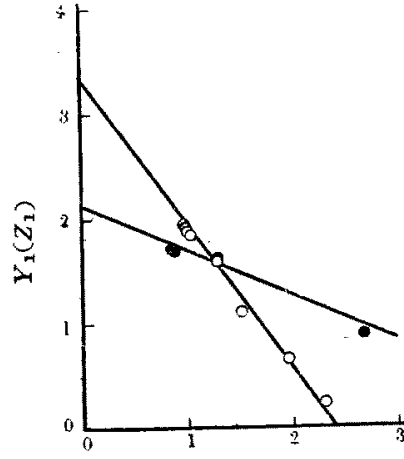

$Y_{1} / Y_{0} \circ\left(Z_{1} / Z_{0} \bullet\right)$

Fig. 4. Diagrams of Finite Differences $\bar{x}_{1}$ to $Y_{1} / Y_{0}$

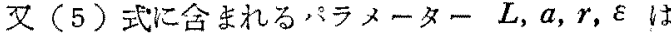
定差図上に得られた值線厄ついて $\tan \theta(\theta$ は直線と $Y_{1} / Y_{0}$ 軸とのな子角）Zび $Y_{1}$ と交る点の $Y_{1}$ 座標か ら求めら机る。即方定差 $h=1$ のとき得られる定差

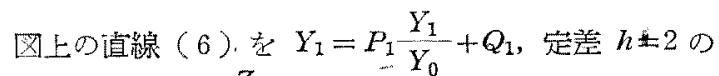
場合を $Z_{1}=P_{2} \frac{Z_{1}}{Z_{0}}+Q_{2}$ としグラフにより $P_{1}, Q_{1}$, $P_{2} ， Q_{2}$ を求め，こ机によつて $L ， r ， \varepsilon$ 在計算する。 aは献間法によつて計算する。このよ5にして Table 1 の測定值（本春験では $y$ 座標には総菌数そのものて なくその対数を用いた）から計算された結果をTable

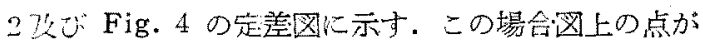
直線上にあることから細菌発育曲線が VERHURST の

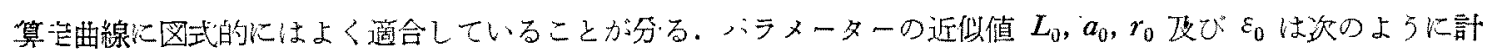
算されたが図式的沉求められた くいちがつているが，上下の計算ては後者の值を用いることにする。

Table 2.

$\begin{array}{lcccccccc}t & \log \bar{I} & Y & Y_{0} & Y_{1} & Y_{1} / Y_{0} & Z_{0} & Z_{1} & Z_{1} / Z_{0} \\ 0 & 0.0073 & 0 & 0 & 0 & & 0 & 0 & 2.6746 \\ 1 & 0.1113 & 0.1040 & 0.1040 & 0.2393 & 2.3010 & 0.3433 & 0.9182 & 2.2828 \\ 2 & 0.3506 & 0.3433 & 0.3433 & 0.6698 & 1.9511 & 1.2615 & 1.6182 & 1.286 \\ 3 & 0.7811 & 0.7738 & 0.7738 & 1.1575 & 1.4959 & 1.9615 & 1.6928 & 0.8630 \\ 4 & 1.2688 & 1.2615 & 1.2615 & 1.6148 & 1.2801 & 2.0361 & 1.7297 & 0.8495 \\ 5 & 1.7261 & 1.7188 & 1.7188 & 1.8575 & 1.0807 & & & \\ 6 & 1.9688 & 1.9615 & 1.9615 & 1.9099 & 0.9737 & & \\ 7 & 2.0212 & 2.0139 & 2.0139 & 1.9321 & 0.9594 & & \\ 8 & 2.0434 & 2.0361 & 2.0361 & 1.9524 & 0.9589 & & & \\ 9 & 2.0637 & 2.0564 & 2.0564 & 1.9690 & 0.9575 & & \end{array}$

但 $h=1$ (hr.), $y_{0}=0, y_{1}=0.1040, y_{2}=0.3433$

$y_{0}=0, \quad y_{1}=0.104, \quad y_{2}=0.343, h=1 ; P_{1}=-1.375, \quad Q_{1}=3.325 ; P_{2}=-0.430, \quad Q_{2}=2.140, \quad$ e-r=X 七す万.

$$
X=\frac{y_{1}+Q_{1}}{y_{2}+Q_{2}}-1=0.381 \quad \text { 涏つて } r=0.965
$$

$L$ は 2 つの方法て求められるのて平均值をとる. $L_{2}=\frac{(1-X)\left(Q_{1}+y_{1}-F_{1}-y_{0}\right)}{1+X}=2.154$, $L_{2}=\frac{\left(1-X^{2}\right)\left(Q_{2}+y_{2}-P_{2}-y_{0}\right)}{1+X^{2}}=2.176, \quad L=\frac{L_{1}+L_{2}}{2}=2.165 \quad \varepsilon=1-\frac{(1-X)\left(y_{1}+Q_{1}\right)}{L}=0.0194$ 
$t=a$ の附近では大体直線をなすものとみなして補間法により $a=3.573$, 又 $\frac{L}{1+e^{r a}}=0.0667$

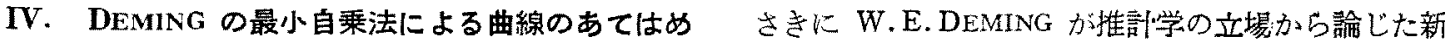
しい最小自乘法は，パラメーターについて線型でない式をあてはあるとき老び $x, y$ 両座標に誤差があるときの

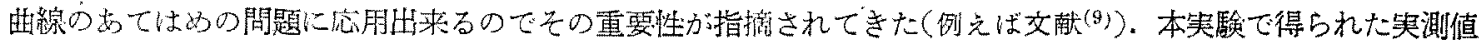
によつて細菌発育曲線が VERHURST の算定时線にどの程度に当てはまるかを梌討することは上の場合汇相当す るので,さらに DEMING の最小自乗法を胕いて曲線のあてはめを行つてみた．組織的扁算の手順及び記号につ

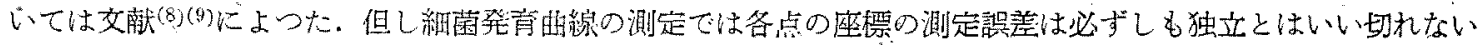
ので各測定愦差の虫立性を前提とした DEMING 浩を用いることには多少問題があるが，他に適当な方法がない ので近似法としてこれによつた。

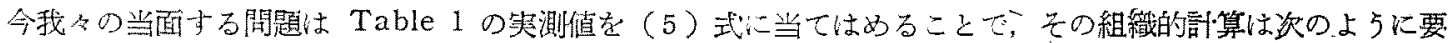
約される。

即b “重㚐をつけた平方和” $S=\sum\left(\omega_{t} V_{t}^{2}+\omega_{y} V_{y^{2}}\right)$ （但し $V$ : は $t$ の牫差， $V_{y}$ は $y$ の残差； $\omega_{t}, \omega_{y}$ は

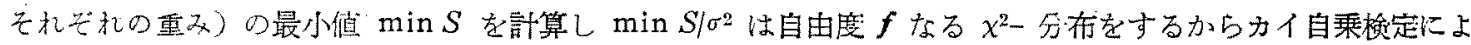
つて曲線の琾諭式への古てはめを行うことになる。

1. 測定值の重みについて（測定值の精度の淮定）

発育曲線を実測したとき培鉒時間 $t$ 及び細菌数の刘数 $y$ の測定值をと狆ぞれ $T$ 乙び $Y$ とし $T=t+E_{t} ， \quad Y=y+E_{y}$ とする.ここで $E_{t} ， E_{y}$ はそれぞれ真の

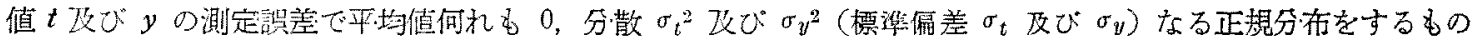
とする。これからの計算に必要な测定值の重みは $\omega_{t}=\sigma^{2} / \sigma_{t^{2}}, \quad \omega_{y}=\sigma^{2} / \sigma_{y}{ }^{2}$ である.但し $\sigma^{2}$ は単に一つの比例

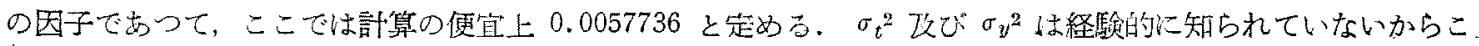
の堨合次の上弓にして定めた。

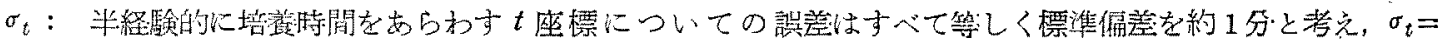
$0.02(\div 1 / 60)$ 乙定める. 但し接種時には $t$ 座標に誤差がない，即ち $\sigma_{t_{\mathrm{c}}}=0$ とする.

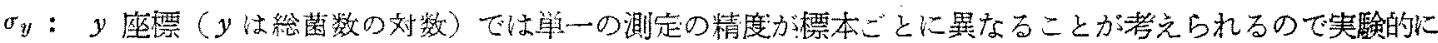

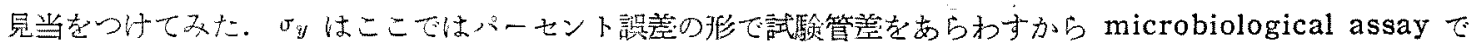

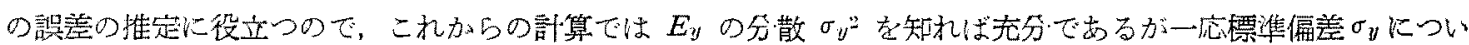

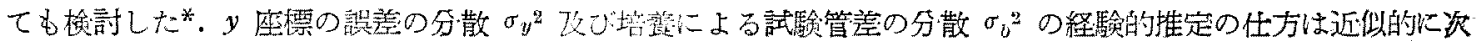
の上うに試みられた关

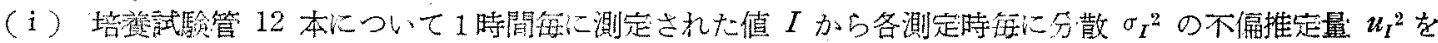

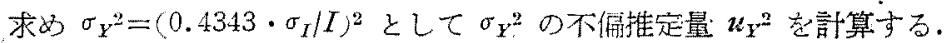

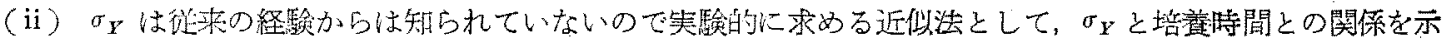

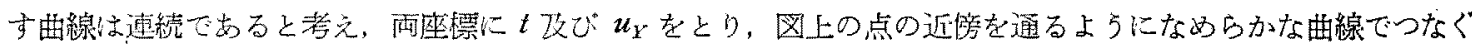
ことにより $u_{Y}$ の值を铺正した。 その禣正傎を Table 3 に $u_{Y}$ (corr.) で表和した。

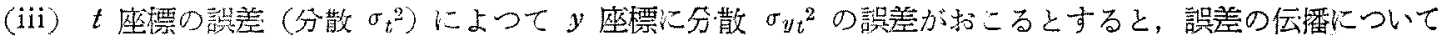
$v^{\prime} t^{2}=\left(F_{t} \cdot \sigma_{t}\right)^{2}$ が成り立つるのとする $\left(F_{t}\right.$ は Table 3 に示した $)$.

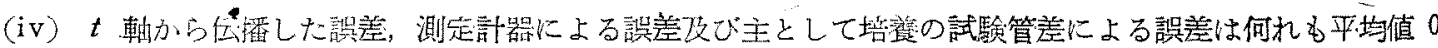

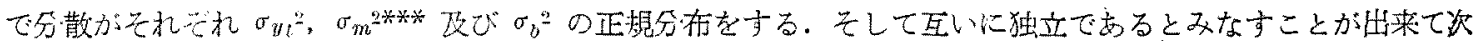

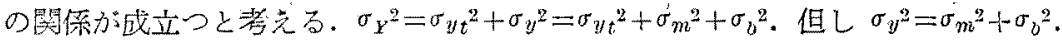

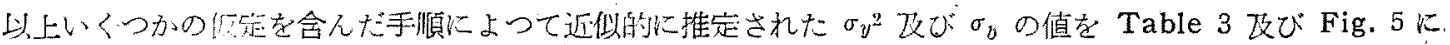

* $u^{2}[=S x /(N-1)]$ は分散 $\sigma^{2}$ の不偏推定量であるが

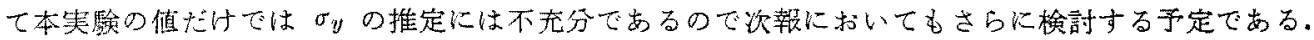

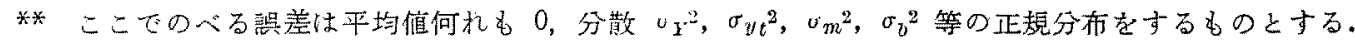

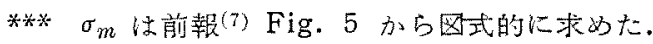

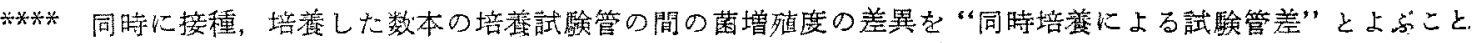
にする（次貝参照） 
Table 3.

\begin{tabular}{|c|c|c|c|c|c|c|}
\hline$t$ & $s_{t}$ & $-F_{t}$ & $\times 10^{-4}$ & $\begin{array}{c}u_{Y} \\
\text { (obs.) } \\
\times 10^{-2}\end{array}$ & $\begin{array}{c}{ }^{t_{Y}} \\
(\operatorname{corr} .) \\
\times 10^{-*}\end{array}$ & $\begin{array}{l}\sigma_{y}^{2} \\
(\text { est. }) \\
\times 10^{-4}\end{array}$ \\
\hline 0 & 0 & 6.2398 & 0 & 4.4276 & 3.75 & 14.06 \\
\hline 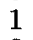 & 0.02 & 14.856 & 29.71 & 3.9416 & 3.65 & 13.23 \\
\hline 2 & 0.02 & 30. & 61.61 & 3.1602 & 3.50 & \\
\hline 3 & 0.02 & 48.427 & 96.85 & 3.1698 & 3.45 & 10.96 \\
\hline 4 & 0.02 & 50.076 & 100.15 & 3.7688 & 3.40 & 10.56 \\
\hline 5 & 0.02 & 33.610 & 67.22 & 3.4267 & 3.00 & \\
\hline 6 & .0 .02 & 16.717 & 33.43 & 2.0207 & 2.40 & 5.648 \\
\hline . & 0.02 & 7.1214 & 14.24 & 1.5562 & 1.90 & 3.590 \\
\hline 8 & 0.02 & 2.8347 & 5.669 & 1.9235 & 1.75 & 3.060 \\
\hline & 0.0 & 1.0988 & 2.198 & 1. 6433 & 1.70 & 2.890 \\
\hline & 0.02 & 0.42133 & 0.8427 & 1.7519 & 1.70 & 2.890 \\
\hline & 0.02 & 0 & 0 & 1.3142 & 1.32 & \\
\hline
\end{tabular}
$F_{t}=-L \cdot r \cdot e^{-r(t-a)} /\left\{1+e^{-r(t-a)}\right\}^{2} ; \sigma_{t} y^{2}=\left(F_{t} \cdot \sigma_{t}\right)^{2}$ if $t=0$, then $\sigma_{t y}=0 ; u_{x}{ }^{2}$ (obs.) $=\left(\log _{10} e\right)^{2}$. $u_{I}{ }^{2} / I^{\overline{2}} ; \sigma_{y}{ }^{2}$ (est.) $)=u_{Y}{ }^{2}$ (corr. $)-\sigma^{2} t y$

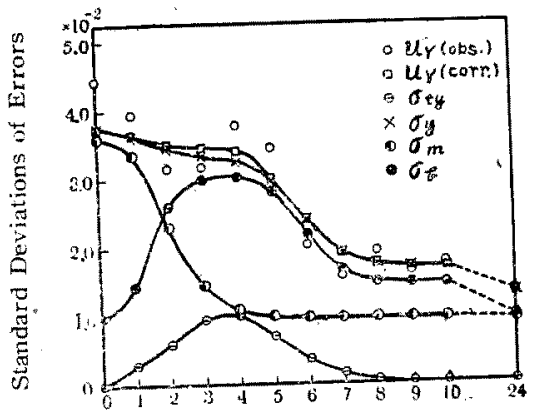

Hours of incub. (l)

Fig. 5. Estimates of Errors in $y$-coordinate 示した。一般に $\log I \equiv$ と寸れば近似的に $\sigma_{p}{ }^{2}=(\log$

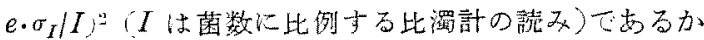

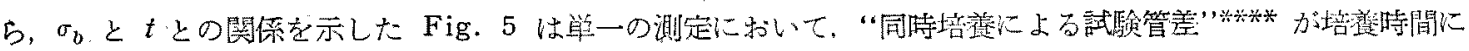

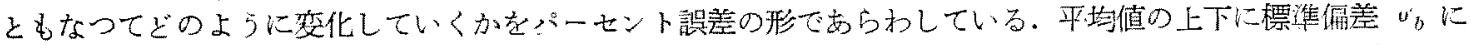

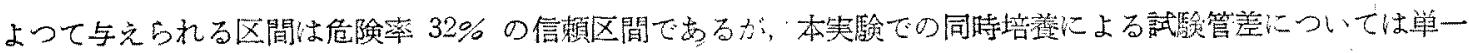

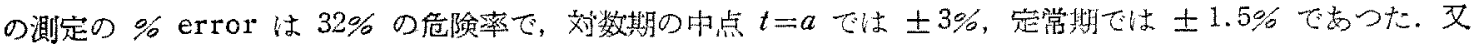

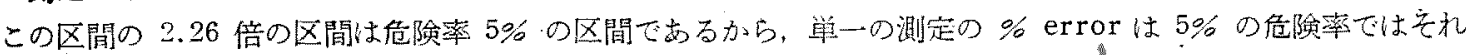

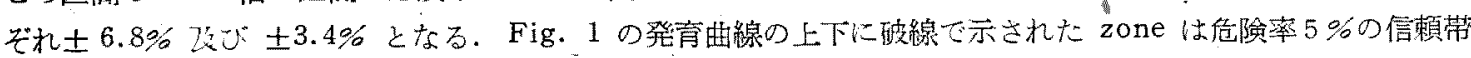
の約 7 倍を示している.

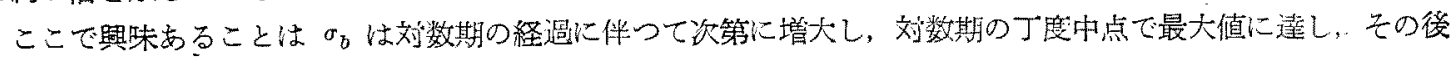
は漸減して定常期に入るとその值は半減してほ添一定になることである。

2. 正規方程式とその解及び Sの最小值の計算計算に必要な函数 $F$ 改びその導函数沈次のよらになる。

$$
F \equiv Y-\varepsilon-\frac{L}{1+e^{-r}(t-a)}
$$

この場合パラメーターは独立ではなく $t=0$ のとき $Y=0$. 优つて $\varepsilon=L /(1$ - era $)$ であるから, 独立なパラメ ーターは $L, a, r の 3$ 個である.

$$
\begin{aligned}
F_{t} & =-\frac{L \cdot \gamma \cdot e^{-r(t-a)}}{\left\{1+e^{-r(t-a)}\right\}^{2}}, \quad F_{Y}=1, \quad F_{0}=Y+\frac{L}{1+e^{r a}}-\frac{L}{1+e^{-r(t-a)}} \\
F_{L} & =\frac{1}{1+e^{r a}}-\frac{1}{1+e^{-r(t-a)}}, \quad F_{a}=-L \cdot r\left[\frac{e^{r a}}{\left(1+e^{r a}\right)^{2}}-\frac{e^{-r(t-a)}}{\left\{1+e^{-r(t-a)\}^{2}}\right.}\right] \\
F_{r} & =-L\left[\frac{a \cdot e^{r a}}{\left(1+-e^{r a}\right)^{2}}+\frac{(t-a) e^{-r(t-a)}}{\left\{1+e^{-r(t-a)}\right\}^{2}}\right]
\end{aligned}
$$

\begin{tabular}{|c|c|c|c|c|c|c|c|c|c|c|c|}
\hline & $N$ & Data & $Y$ & $Y_{y}$ & $1 / \omega_{t}$ & $1 / \omega \bar{z}$ & $W$ & $-F_{L}$ & $F_{a}^{\prime}$ & $F_{r}$ & $F_{0}$ \\
\hline & .12 & 0 & 0 & 67 & 0 & 3.5150 & 0.28418 & 0 & 0 & 0 & 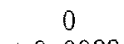 \\
\hline & 12 & 1 & 0.1040 & & 7 & 3. & & 0.046225 & +0.086157 & 16508 & +0.0039 \\
\hline & $\begin{array}{l}12 \\
12\end{array}$ & 2 & 0.3433 & 0 & 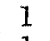 & 2.9 & 0.3265 & .14894 & +.2 & $\begin{array}{l}+.27112 \\
+\quad 056528\end{array}$ & + \\
\hline 4 & $\begin{array}{l}12 \\
12\end{array}$ & 3 & 0.7 & & 1 & 2.7 & & .3 & $\begin{array}{l}+.42 \\
+\quad .43\end{array}$ & $\begin{array}{l}+.05 \\
-.44\end{array}$ & $\begin{array}{l}+.0001 \\
+\quad .0259\end{array}$ \\
\hline & $\begin{array}{l}12 \\
12\end{array}$ & $\begin{array}{l}4 \\
5\end{array}$ & $\begin{array}{l}1.2 \\
1.7\end{array}$ & 1.7 & $\begin{array}{l}1 \\
1\end{array}$ & $\begin{array}{l}2.6 \\
2.1\end{array}$ & & .76 & $\begin{array}{r}+.45 \\
+\quad .27\end{array}$ & $\begin{array}{l}=.44 \\
-.72\end{array}$ & $\begin{array}{r}+.0259 \\
+\quad .0567\end{array}$ \\
\hline & 12 & 6 & 1.9 & 2.02 & 1 & 1.4 & & & +.10 & -.65 & +.0531 \\
\hline$\gamma$ & 12 & 7 & 2.0 & 2. & 1 & 0.89750 & 1. & .9 & +.0088164 & -.48394 & 0079 \\
\hline & 12 & 8 & 2.0 & 2.10 & 1 & 0.76500 & 1.3 & .955 & & - & \\
\hline & 12 & 9 & 2.0 & & & & & & - & 29 & \\
\hline & 12 & 10 & 2.0730 & 2.1397 & 1 & 0.72250 & 1.38404 & & -058184 & $\begin{array}{c}-.25909 \\
12 \sigma^{\sigma^{3}} ; 1 / \omega_{y}=\sigma\end{array}$ & $2 / 2$ \\
\hline
\end{tabular}

パラメーターの近似值としては四式的に求められた $L_{0}=2.165, a_{0}=3.573 ， r_{0}=0.965$ なる值老胿るる。

行列淮備表，行列攻び正替方程式の解を Table 4, Table 5 に示与.

$$
\text { Table 4. Data, Weights and Derived Functions }
$$


以上の計算の結栔をまとめると次のようになる。

(i ) $\chi_{0}^{2}=\min _{\sigma^{2}}^{2}=\frac{0.16654 \times 10^{-2}}{\left(0.57736 \times 10^{-2}\right)^{2}}=49.961$

自由度 $\boldsymbol{f}=11-3=8$

$\therefore P r\left\{\chi^{2} \geqq \chi_{0}^{2}\right\}<0.001$ 侹つて DEMING の最小自乗法による適合度の梌定では垁測值から得られ た曲線はVERHURST の算定曲線（4）式汇蹢合してい るとはい点ないこと分分る。

(ii) Table 5 の $U, V$ 改び $W$ の值を用いてパラ ターターの調整值を求めると

$$
\begin{aligned}
& L=L_{0}-U=2.165-0.041704=2.123296 \\
& a=a_{0}-V=3.573-0.130873=3.442127 \\
& r=r_{0}-W=0.965+0.069884=1.034884 \\
& \varepsilon=L /(1+\text { era })=0.0585737
\end{aligned}
$$

さきに图式的に求められたパラメーターの近似值はこ の調整値に対し約 7\% 以下のくいちが、止つている.

V. むすび 本報では主として細菌発育曲線のVERHUST の人口增加の算定曲線へのむてはめの方法につ いて檢討したが，DEMING の最小自乗法で必要な測定 値の重文の推定の仕方については問題が残されている。 もし本報で行方九た $y$ 座標の誤差の推定の仕方が近似的 に正しいとすれば，Fig. 5 に示された $t$ 対 $v_{b}$ 曲線は 対数期の注添中心て最大值走示し; 定常期に入ると共に 約半減して水平になるという興味ある結果を示してい る.この点については更に多くの㹬験例について次報で 榆討を重初る予定である。

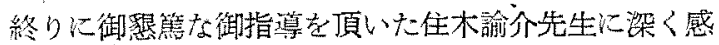
謝すると共御教示と御批判を与えられた堌山元三郎， 森口繁一雨氏兹びに在々潪也氏に厚く謝意を素する。 本研究は文部省科学研究費によつて行的机た（本研究の 要旨は昭和 24 年 6 月 25 日第 102 回日本濃芸化学会東 京支部例会に於いて講演したう

(1) MCKENDRICX and PAI: Proc. Roy. Soc., Edinburgh, 31, 649 (1911).

(2) Robertoson : J.Physiol., 56,404 (1922); The Chemical Basis of Growth and Senesc. ence. (1923).

(3) Thornton: Ann. Appl. Biol., (1922), 265.

(4) LotKA : Elements of Physical Biology, (1925).

(5) Pulley and Greaves: $J$. Bact., 24. 145 (1932).

(6) 值來： J. Antibiotics., 4, 155 (1951).
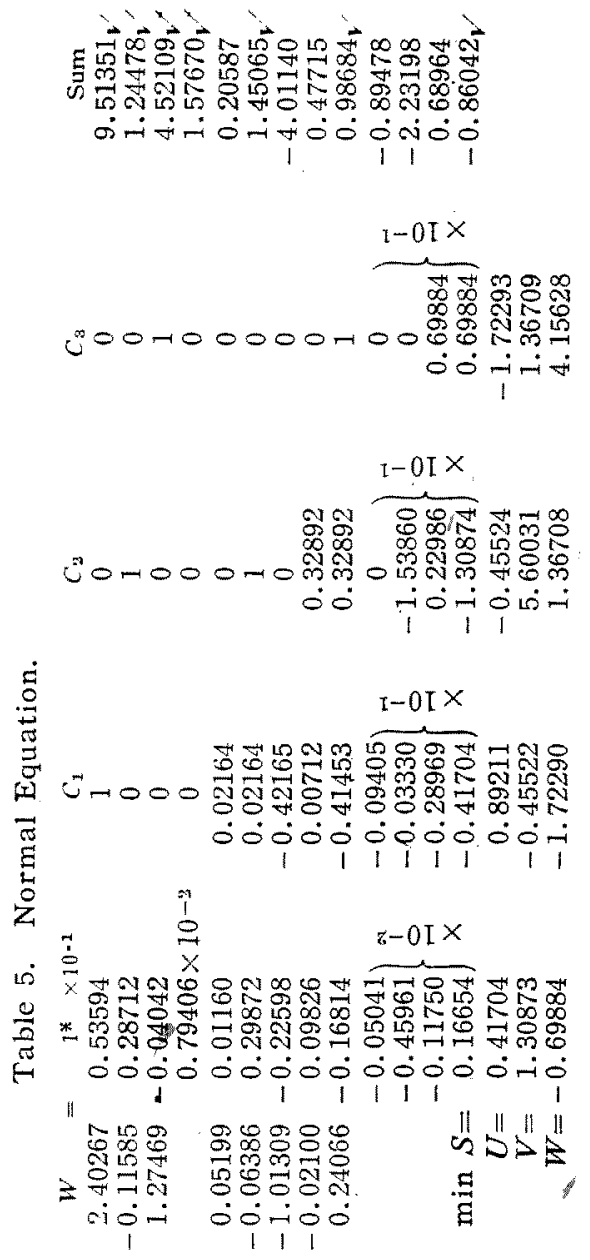

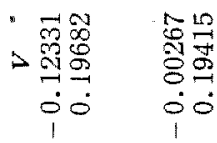

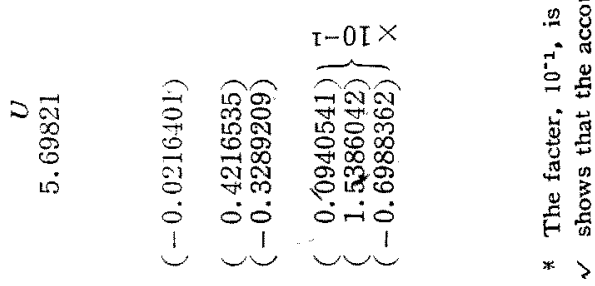

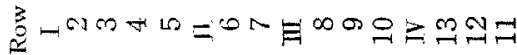

(7) 松山：農化，23，156 (1949).

(8) Deming: Statistical Adjustment of Data, (1946)

(9) 森口：科学, 18，478（1948): 推計学化よ るデータのまとめ方 (1950)。 


\section{Summary}

The growth of the bacteria (Escherichia coli) was measured using the photoelectric turbidimeter, and the fitness to logistic curve (4) introduced by VERHURST was examined. 'The results were as follows ;

I. (i) The variable $y$ in the equation (4) has been defined as $y \equiv Y+\varepsilon$, where $Y$ is the bacterial turbidity ( $\log$ ) established so that the turbidity at the time of the inoculation may be zero, and $\varepsilon$ is $L /\left(1+e^{r \alpha}\right)$. $Y$ is observable but $\varepsilon$ is unknown.

(ii) The equation (6) of finite differences derived from the equation (4) is used to examine the graphical goodness of fitting to the logistic curve (4). The points on this diagram of finite differences (Fig. 4) are on a straight line, and this fact means the graphical good fitness.

(iii) Parameters $L, r$ and $\varepsilon$ are calculated diretcly from the value of $P_{1}, Q_{1}, P_{2}$, and $Q_{2}$, but the estimate of $\varepsilon$ is adopted from the value of the $L /\left(1+e^{r a}\right)$. By means of interpolation, $a$ is estimated.

II. According to the method of the least squares presented by W. E. DEMING, the minimum value of the sum of the weighted squares was calculated.

In order to determine the weights in $y$-coordinate, the standard deviations of the errors caused by incubation and measuring were estimated experimentally (Fig. 5). As the result of chi square test in which $\chi_{0}{ }^{3}=\min S / \sigma^{2}=49.949$, degree of freedom $=8$, and $\operatorname{Pr}\left\{\chi^{2} \geqq \chi_{0}{ }^{2}\right\}<$ 0.001 , it cannot be allowed that the growth curve of the bacteria follows the logistic curve (4).

\section{火成岩の風化に関する研究（第 9 報） 花崗岩の風化（1）}

\section{原 田 光 (鳥取大学学芸学部) 昭和 27 年 5 月 12 日受理}

Studies on the Weathering of Igneous Rocks. Part 9. On the Weathering of Granite (1) By Mitsuru HARADA (Department of Liberal Arts, Tottori University)

I. 語料（1）鳥取花萹岩改びその風化座物。鳥取市栗谷に於て次の試料を採集した（年平均気温 $1^{\circ}$ ， 年降水量 $1931 \mathrm{~mm}$ ).

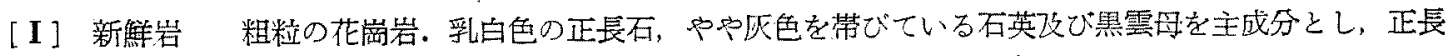
石は特に大きく，幾分斑状を呈している。[II] 風化岩 本試料はなお母岩の組織を有するが，僅かに压力を 加えると容易に破砕される部分である。黑雲母鉄を分離して谈鱼となり，長石は全く不透明となり，なた酸化 鉄により活染されている：新鮮岩から風化岩へは徐タに移行し，両者間に明睹な境界がない，地表から約 $4 \mathrm{~m} の$ 梁さに於て試料を採集した．［II b] 割目沈搌物 岩石中にある割目を充している白色の土状の物賀. 湿る时湛

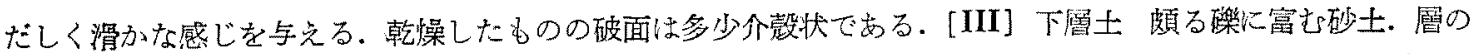
厚さ約 $1 \mathrm{~m}$ ，試料は之の中央，地表面から $80 \mathrm{~cm}$ の所で採集した。淡色の黑雲母片攻び分解不十分な正長石の 粒子が含まれている. [IV] 表買土 橾比富む淡褐色の砂土. 層の厚さ $30 \mathrm{~cm}$, 地表から $15 \mathrm{~cm}$ の所で試料を

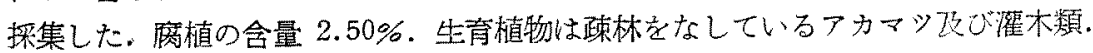

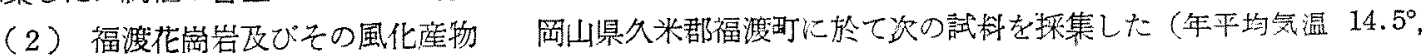
年降水量 $1200 \mathrm{~mm}$ 推定). [I] 新蟹岩 これは中粒の黑雲母花崗岩で, 淡紅色の正長石, 淡灰色の石英及び黑

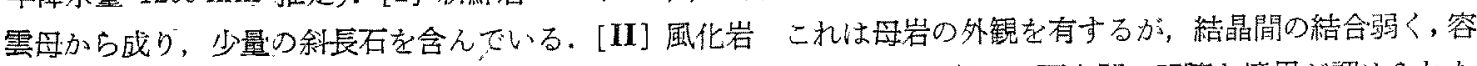
易飞破砕される部分である。前例と同様に新焦岩から風化岩に过第に移行し，両者間火眀瞭な境界が認められな い. 雲母恃金色を呈し，雲母から分離した酸化鉄に上りその用囲淡褐色となり，正長石は全く不透明となつてい るがな怙結晶形を保つている，層の厚さ約 $2 \mathrm{~m}$ ，試料はての中央，地表から $1.5 \mathrm{~m}$ の所に於て採集した。

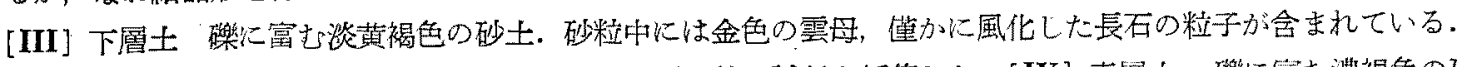

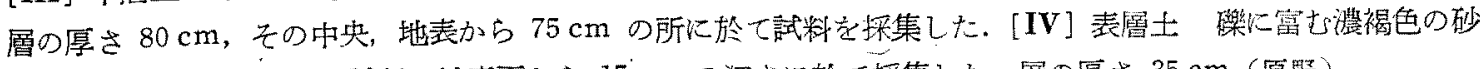

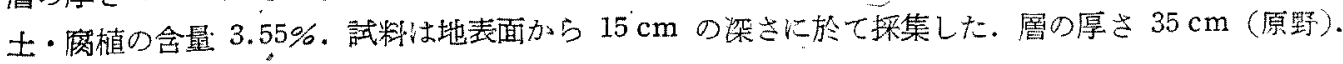

